\title{
Studi Kasus Siswi SMP dibully dan dikeroyok Oleh Siswi SMA
}

(Diajukan sebagai salah satu syarat kelulusan mata kuliah Filsasat Manusia yang dibina oleh Bapak Agustinus W Dewantara, S.S.,Hum)

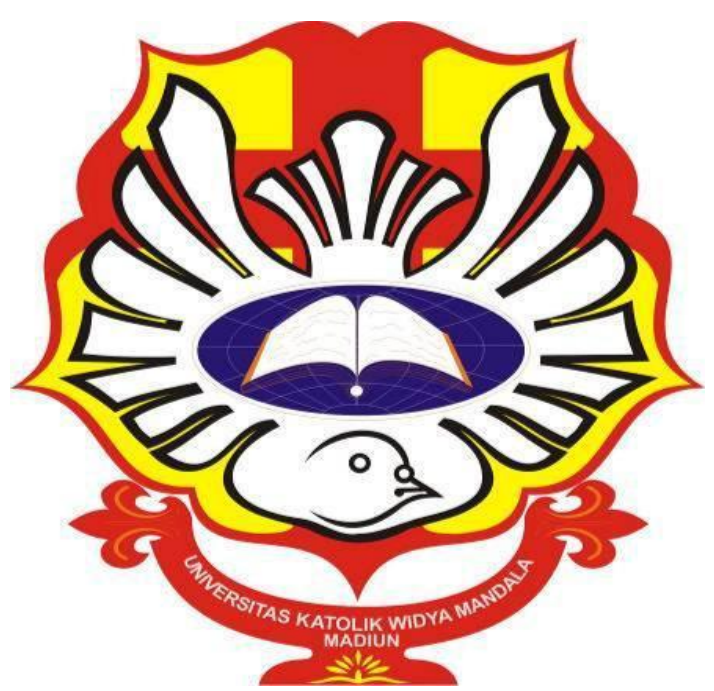

Disusun Oleh :

Danny Chandra Septian

Dannycseptian.dc@gmail.com

NIM. 41415003

\section{PROGRAM STUDI TEKNIK INDUSTRI}

FAKULTAS TEKNIK

UNIVERSITAS KATOLIK WIDYA MANDALA

MADIUN 


\section{PENDAHULUAN}

Bullying sering dikenal dengan istilah pemalakan, pengucilan, serta intimidasi. Bullying merupakan perilaku dengan karakteristik melakukan tindakan yang merugikan orang lain secara sadar dan dilakukan secara berulang-ulang dengan penyalahgunaan kekuasaan secara sistematis. Perilaku ini meliputi tindakan secara fisik seperti menendang dan menggigit, secara verbal seperti menyerbarkan isu dan melalui perangkat elektronik atau cyberbullying. Semua tindakan bullying, baikfisik maupun verbal, akan menimbulkan dampak fisik maupun psikologis bagi korbannya.

Dampak bullying pada korban diantaranya kesehatan fisiknya menurun, dan sulit tidur. Seorang korban juga cenderung memiliki psychological well-being yang rendah, seperti perasaan tidak bahagia secara umum, self-esteem rendah, perasaan marah, sedih, tertekan dan terancam ketika berada pada situasi tertentu. Secara psikologis, seseorang korban akan mengalami psychological distress; misalnya adalah tingkat kecemasan yang tinggi, depresi dan pikiran-pikiran untuk bunuh diri Secara akademis seorang korban akan mengalami poor results; prestasi akademis menurun, kurangnya konsentrasi korban Oleh karena dampak bullying yang banyak dan sangat merugikan korban, fenomena ini harus bisa ditangani. Salah satu cara dengan tindakan preventif yaitu intervensi terhadap pihak-pihak yang terlibat dalam situasi bullying.

Bullying terjadi dalam berbagai bentuk diantaranya yaitu bullying secara verbal perilaku berupa kritikan kejam, fitnah, penghinaan. Bullying secara fisik dengan memukuli, menendang, menampar. Bullying secara relasional merupakan pelemahan harga diri korban secara sistematis melalui pengucilan, pengabaian, atau penghindaran. Sedangkan bullying secara elektronik bisa dengan mengirimkan pesan atau image melalui internet atau telepon seluler. Bentuk bullying tersebut bisa terjadi di kalangan pelajar maupun masyarakat luas, tidak terkecuali pada pengguna internet atau media massa elektronik lainnya. Pelaku bullying pada media massa elektronik biasanya dilakukan dengan memposting 
gambar atau foto seseorang dengan meminimalisir memodifikasi minimal sehingga pembaca masih mudah mengenali korban. Tidak hanya gambarnya saja yang dimodifikasi serta di-upload dalam akun jejaring sosial, namun pelaku bullying juga menambahkan kata-kata yang tidak pantas dibaca, mengolok-olok, melecehkan, mencaci maki, bahkan menghina. Selama Pemilihan Presiden dan Wakil Presiden, baik pada pemilihan Presiden tahun 2014 maupun tahun 2009, pendukung Calon Presiden dan Wakil Presiden melakukan perang sosial media, baik dengan wujud kata-kata ataupun design grafis. Dalam pilpres 2009 terdapat beberapa pelanggaran atau kasus yang terjadi selama berlangsungnya pilpres sampai selesainya pemungutan suara yang terulang selama dua kali putaran yang disebabkan adanya kesenjangan antar capres pada masa itu. Kasus yang terjadi dalam pilpres 2009 diantaranya money politik, kecurangan dalam proses pemungutan suara, pemilih yang memilih lebih dari satu kali, sampai warga yang tidak punya hak pilih memaksa untuk memilih. Beberapa kasus yang dilaporkan dari berbagai daerah ditangani oleh Bawaslu, kasus yang paling banyak yaitu di Provinsi Jawa Tengah. Pilpres pada tahun 2009 juga mengalami tindakan Bullying yang dirasakan oleh para calon Presiden, baik berupa kata-kata yang tidak pantas sampai mengolok-olok. 


\section{KRONOLOGI KASUS}

Pada studi kasus yang cukup viral pada tahun ini yaitu Kasus siswi SMP Audrey yang di Bully dan dikeroyok siswi SMA. Seperti yang diberitakan, Audrey dianiaya oleh belasan siswi SMA hingga memar sekujur tubuh. Pengeroyokan terjadi pada Jumat 29 Maret 2019, pukul 14.15 WIB. Korban yang berada dirumah dijemput oleh temannya, dengan tujuan kerumah sepupunya. Berikut fakta terkait kasus tersebut:

\section{Pelaku Diancam Dibunuh}

Usai kejadian tersebut, pelaku dan keluarga kerap mendapatkan ancaman dari sejumlah oknum yang tak dikenal. Pihaknya diancam dibunuh, disekap hingga ada yang mengaku akan menusuk kemaluannya. Dengan kejadian tersebut pihak KPPAD ikut turun mendampingi korban mengingat baik pelaku maupun korban sama-sama di bawah umur.

\section{Fakta Pemukulan di Perut}

Ternyata terduga pelaku berkali kali memukul perut Audrey. Seperti dikutip tribuntimur.com dari tribunPontianak, awalnya penganiayaan dimulai saat korban dijemput $\mathrm{D}$ menuju rumah $\mathrm{P}$. Dari rumah $\mathrm{P}$, korban keluar menggunakan roda dua dan diikuti dua sepeda motor yang pengendaranya tidak dikenal korban. Setelah sampai di Jalan Sulawesi, korban dicegat. Tiba-tiba dari arah belakang, terduga pelaku, E menyiram air dan menarik rambut korban sehingga terjatuh. Setelah korban terjatuh, E menginjak perut korban dan membenturkan kepala korban ke aspal. Setelah itu, korban melarikan diri bersama P menggunakan sepeda motor. Namun korban dicegat kembali oleh saudari $\mathrm{T}$ dan saudari L di Taman Akcaya yang tidak jauh dari TKP pertama. Setelah itu, korban dipiting oleh T. Selanjutnya L menendang pada bagian perut korban. Namun saat kejadian itu dilihat warga sekitar, sehingga pelaku melarikan diri. 


\section{Soal Kemaluan}

Awalnya heboh menyebut kemaluan Audrey rusak karena ikut menjadi sasaran pukulan terduga pelaku. Namun ternyata hasil visum menyebutkan, tidak ada kerusakan di kemaluannya. Diungkap polisi, luka hanya terdapat di perut.

\section{Bahas Utang Piutang}

Fakta lain terungkap bahwa salah satu pemicunya adalah soal utang. Menurut Kapolresta, perkelahian terjadi karena satu di antara mantan pacar pelaku adalah pacar dari sepupu korban. Tak hanya itu, satu di antara orang tua terduga pelaku pernah meminjam uang kepada korban sejumlah Rp 500 ribu dan sudah dikembalikan namun sering diungkit. 


\section{TEORI INTELEK, KEHENDAK, DAN \\ DINAMIKA MANUSIA}

Permasalahan intelek adalah soal mengerti, sedangkan kehendak adalah soal kemauan. Lalu apakah keduanya merupakan dua bagian yang terpisah dan esensial? Lalu apa hakikat dan keduanya? Mengerti dan menghendaki kerap kali di maknai sebagai inti kegiatan. Intelek memilah dan kehendak mengapresiasi. Ada evaluasi intelektual dan evaluasi afektif. Kedua evaluasi ini Nampak dalam kegiatan rohaniah dan jasmaniah, semakin saya mengevaluasi secara intelektual, semakin pula saya mengevaluasi secara afektif. Inilah makna dari makin manusiawi, maka pertumbuhan yang manusiawi adalah makin rasional dan sekaligus afektif.

Manusia di satu pihak mempunyai kebebasan, tetapi di lain pihak juga tergantung. Ketika memutuskan. Manusia bebas, tetapi setelah itu ia harus tunduk pada apa yang sudah diputuskan. Aliran determinisme mengatakan bahwa manusia itu tidak bebas dan ditentukan oleh unsur-unsur lain ( Hegel: dialektika Roh, Spinoza, substansi mutlak penentu segala sesuatu, dan Carl Gustav Jung: manusia bergantung pada hukum yang ada), manusia menentukan dirinya sendiri, Atomistis: semua adalah peristiwa atom yang terjadi secara kebetulan), Konflik dalam memahami kebebasan terjadi antara paham determinisme dan interdeterminisme. Hal ini terjadi dalam uraian berikut:

a. Jika dasar yang dipai adalah subjek itu tudak bebas:

i. Secara spiritalistik

Bertolak dariaku yang sudah dideterminasi (tidak bebas), kehendak kebebasan manusia termnyata sudah diarahkan pada hal yang baik. Dalam kenyataannya kegendak manusia itu ternyata masih pula kebebasan, meski sudah terarah kepada apa yang baik. Hal ini terjadi karena kepentingan subjek. 


\section{ii. Secara materialistik}

Subjek itu tidak bebas, akrena kegiatannya sudah diatur oada keharusan alamiah (mengikuti hokum matari). Tapi ternyata juga masih bebas untuk memilih.

b. Jika yang dipakai dasar adalah subjek itu bebas:

i. Secara spiritualistik

Manusia memang ada dalam peristiwa kosmis, tetapi ia tidak terikat pada itu semua. Manusia tetap bebas ketika berhadapan dengan alam, karena manusia punya kebebasan intrinsik.

iii. Secara materialistik

Manusia itu tumbuh tanpa ada yang merintangi. Di lain pihak perkembangan psikis manusia ditentukan pula oleh hal-hal lain.

Sintese dari semua itu adalah: Manusia tidak bisa diyentukan dari suatıu determinasi atau indeterminasi. Kegiatan manusia selalu diwarnai sebagai aku yang bebas dan aku yang terarah kepada sesuatu. Ada doimensi aktif dan pasif sekaligus.

Jadi hakekat manusia adalah suatu keharusan (manusia menerima suatu keniscayaan kodrati), suatu kebebasan (mansuaia itu otonom dan unik). Kcharusan dan kebebasan ini ada dalam satu kesatuan substansial. Dnegan kata lain, manusia itu kebebasan yang mengharuskan, dan keharusan yang membebaskan. Di dalam kebebasan termuat keharusan, dan di dalam keharusan termuat kebebasan. 


\section{HUBUNGAN ANTARA KASUS SISWI SMP AUDREY YANG DI BULLY \\ DAN DI KEROYOK OLEH SISWI SMA DENGAN TEORI INTELEK, KEHENDAK, DAN DINAMIKA MANUSIA}

Setiap tindakan dan kebebebasan yang dimiliki manusia pola geraknya masih terikat dengan ketentuan yang sudah pasti. Jadi pada kasus tersebut belasan siswi SMA yang tidak memiliki rasa bersalah telah membully dan mengeroyok siswi SMP. Dengan perlakuan pembullyan tersebut tersangka terikat dengan UU perlindungan anak dibawah umur yang harus di urusi dengan kepolisian. Hukuman yang sesuai dengan perbuatan mereka dan tersangka juga masih di bawah umur. Faktor yang sangat mempengaruhi tingkah laku,perasaan, dan pikiran manusia itu dari lingkungannya budayanya yang sangat mempengaruhi.

Dengan demikian manusia dituntut bersikap bijak dalam mengambil keputusan, perbuatan perlilaku, jangan mudah menghakimi dan menyalahkan orang lain karena tindakan apa pun ada faktor luar yang kadang kala memaksanya untuk melakukan. 


\section{DAFTAR PUSTAKA}

Dr. Agustinus W. Dewantara, S. M. (2019). Diktat Kuliah FILSAFAT MANUSIA. Madiun.

Tribunnews. (2019, April 11). Tribun-Timur.com. Retrieved Juni 29, 2019, from 7 Fakta Terbaru Siswi SMP Dikeroyok Siswi SMA, Guru Ungkap Sifat Asli Audrey Hingga Bahas Utang: https://makassar.tribunnews.com/2019/04/11/7-faktaterbaru-siswi-smp-dikeroyok-siswi-sma-guru-ungkap-sifat-asli-audrey-hinggabahas-utang?page $=4$

Dewantara, Agustinus Wisnu. "Pancasila Sebagai Pondasi Pendidikan Agama Di Indonesia." CIVIS 5.1/Januari (2015). 